\title{
TRADUÇÃO DO CONTO “MiSSING OUT”, DE LEILA ABOULELA
}

\section{“MISSING OUT": A SHORT STORY BY LEILA ABOULELA TRANSLATED INTO BRAZILIAN PORTUGUESE}

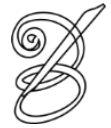 \\ Ana Luiza de OLIVEIRA E SILVA* \\ Canadian Council for International Cooperation (CCIC-CCCI) \\ Ottawa, Ontario, Canadá
}

Resumo: O conto intitulado "Missing Out" data de 2010 e traz à tona temas frequentes na literatura de Leila Aboulela. Nascida em Cartum, capital do Sudão, esta autora africana parte de uma situação de imigração para tratar de questões como a distância, a saudade de casa, a solidão, e o (não-)pertencimento. Outro elemento presente no conto refere-se à aproximação/afastamento da religião, no caso, o Islã, e de que maneira este aspecto afeta as personagens. A tradução do original em inglês para o português tem como objetivo principal oferecer acesso a uma autora premiada e, no entanto, pouco conhecida entre o público leitor lusófono, de modo a despertar o interesse pela literatura africana, especialmente de autoria feminina.

Palavras-chave: Tradução. Conto africano. Sudão. Leila Aboulela.

Abstract: First published in 2010, the short story "Missing Out" illustrates many of the recurring themes in Leila Aboulela's writing. Born in Khartoum, capital of Sudan, Aboulela uses immigration as a point of departure to address issues such as distance, homesickness, loneliness, and (non-)belonging. Another element present in the story is proximity to/distance from religion - in particular, Islam-and how it affects the characters. The translation of the original, from English into Portuguese, aims to offer access to a celebrated author, still relatively unknown in the Lusophone world, in order to raise interest in female-written African literatures.

Keywords: Translation. African short story. Sudan. Leila Aboulela.

RECEBIDO EM: 01/10/2019

ACEITO EM: 13/02/2020

PUBLICADO EM: março 2020 


\section{Sobre a autora e obra}

7 eila Aboulela ${ }^{1}$ nasceu no Cairo em 1964 e cresceu na cidade sudanesa de Cartum. Formou-se em economia pela Karthoum University e possui mestrado em estatística pela London School of Economics. A partir de 1990, viveu em diversos países, como Indonésia, Emirados Árabes e Catar, e atualmente reside na Escócia. Seu primeiro livro, "The Translator", datado de 1999, foi indicado ao Orange Prize e escolhido como livro do ano pelo New York Times em 2006. O conto aqui traduzido para o português, "Missing Out", data de 2010 - período de grande instabilidade sócio-político-econômica no Sudão - e, aparentemente, também recebeu tradução para o árabe. ${ }^{2}$

Pelas informações que pudemos coletar, "Missing Out" trata de temas caros à autora, os quais também se encontram presentes em outras de suas obras. Em julho de 2018, o jornal The Guardian publicou uma resenha acerca de uma coletânea de contos de Leila Aboulela intitulada "Elsewhere, Home". De acordo com a resenhista, questões como a distância, a saudade de casa [homesickness], a solidão, o Islã, e os embates entre Oriente e Ocidente - e talvez seja possível estendê-los àqueles ocorridos entre tradição e modernidade - encontramse ao longo das diversas narrativas da coleção. Assim, "Missing Out" parece marcar temáticas frequentemente exploradas por esta autora africana.

Em 2011, a estória foi publicada em uma coletânea de contos africanos intitulada "The Granta Book of the African Short Story". ${ }^{3}$ Seu editor, Helon Habila, ao justificar suas escolhas na composição da coletânea, escreveu: “[...] eu me fazia uma pergunta simples: daqui a dez anos, esta estória vai lançar luz sobre as preocupações e inquietações, tanto literárias quanto sociais, da época em que foi escrita?"4 É possível perceber que os aspectos trazidos à tona pelo conto "Missing Out", particularmente aqueles tocantes à imigração e ao pertencimento, revelam questões presentes não apenas em seu período de criação, mas ainda hoje, e talvez mesmo futuramente. Neste sentido, o conto não se esgota em uma determinada época, mas fala de realidades e experiências que se alongam no tempo.

\section{Sobre a tradução}

A tradução de "Missing Out" teve início a partir de uma proposta de trabalho com contos africanos lançada por Janice Nodari, docente do curso de Letras da Universidade Federal do Paraná. No tocante aos desafios relativos à tradução, o primeiro se deu logo no título do conto. O termo to miss something out pode ser compreendido como “perder"; não no sentido de extravio, privação ou perda de uma posse [to lose], mas sim na acepção de deixar 
algo passar por entre os dedos [to let something slip through one's fingers], ou ainda na de ser deixado de fora [be left out]. Cogitaram-se algumas traduções possíveis, como "Estar/Sair/Ficar perdendo", ou "Ficando de fora". Por fim, decidiu-se por "Deixar passar"; tradução mantida tanto no título quanto nas duas vezes em que o termo missing out aparece ao longo do texto.

No processo de tradução do conto, foi respeitado o princípio de Henri Meschonnic no tocante ao marcado/não marcado (cf. MESCHONNIC, 1973). Assim, palavras não inglesas como, por exemplo, tobe, siesta e inshallah, foram mantidas tais como se encontram no original. Outro elemento bastante marcado no texto é a mistura de tempos verbais do passado e do presente, a qual pode ser entendida como uma estratégia literária que visa "presentificar" uma memória, trazendo-a para o momento de fala/pensamento da personagem. Buscou-se manter esta estratégia também na tradução. Ainda outro aspecto bastante presente no original é o uso de vírgulas sequenciais para dar a noção de continuidade a uma ideia, como um encadeamento de pensamentos, e o uso de pontos finais para marcar ou enfatizar informações. Este artifício literário foi mantido tanto quanto possível, de modo a não descaracterizar o ritmo frasal do texto.

Em relação a outras opções tradutórias, os nomes de cidades foram transferidos para o português, como no caso de Londres [London] e Cartum [Karthoum], ao passo que lugares mais específicos, como University Road, foram mantidos em inglês. Foram suprimidos quaisquer usos de mesóclise; por exemplo, ao invés de "juntar-se-iam", a opção foi por "se juntariam". Além disso, o texto original faz um imenso uso de possessivos, especialmente his e her, que muitas vezes foram suprimidos, ou pela redundância - por exemplo, em uma longa descrição da personagem feminina, torna-se desnecessário e/ou repetitivo referir-se ao "cabelo dela", ou "seu cabelo", estando implícito que apenas "o cabelo" se refere a "ela" - ou para evitar ambiguidades, como nos inúmeros casos em que a tradução para o português recairia no uso de "seu" (dele ou dela?).

No tocante a palavras de caráter sensorial, Paulo Henriques Britto, em texto intitulado "A tradução literária", menciona a dificuldade de se traduzir termos relativos aos sentidos da audição e visão. ${ }^{5}$ Ocorreram, de fato, obstáculos desta natureza durante a tradução de "Missing Out": por vezes, foi possível utilizar palavras como "chapinhar" [splash] e "baque" [thud]; por outras, termos diversos, como brilliant, glistening, bright e shining, foram todos traduzidos como "brilhante" ou "reluzente". 
Quanto aos diálogos, optou-se por, como sugerido por Paulo Henriques Britto, inserir "marcas de oralidade" de modo a criar um "efeito de verossimilhança". ${ }^{6}$ Dentre as estratégias levantadas pelo referido autor ${ }^{7}$, foram utilizadas marcas fonéticas (como "pra"), lexicais (como "burra"), e morfossintáticas (como o uso de "ter" no sentido de existir; a mistura da segunda e terceira pessoa do singular, como, por exemplo, em "Não acabei de te dizer que eu não quero as suas tralhas?"; o uso redundante de pronome sujeito, como no caso de "Eu fui reprovado"; entre diversos outros exemplos).

\section{Deixar passar}

Em Londres, no primeiro semestre da faculdade, Majdy escrevia cartas para casa anunciando que não daria conta, ameaçando desistir e voltar. Para falar com ele por telefone, a mãe tinha que fazer diversas viagens até o Correio Central de Cartum, onde ficava sentada por horas no banco baixo de madeira, abanando o rosto com a ponta do tobe no calor sufocante e enxotando as crianças descalças que passavam com bandejas carregadas tentando vender chicletes, grampos de cabelo e fósforos. "Sai da minha frente", brigou ela com a garota que havia se esgueirado pelo lado e estava praticamente se apoiando em seu colo. "Não acabei de te dizer que eu não quero as suas tralhas?" No terceiro dia, a mãe conseguiu; enfiouse em um cubículo sem fechar a porta de vidro atrás de si.

Majdy ficou com a garganta apertada quando ouviu a voz dela. No fresco corredor do alojamento, ele segurou o gancho do telefone e apoiou a cabeça contra a parede, escondendo o rosto na dobra do braço. Os estudantes que passaram por ele andaram um pouco mais depressa, sentindo-se um pouco desconfortáveis ao ouvir sua voz pesada de lágrimas e estranhamente alta; palavras estrangeiras que eles não compreendiam ecoando e perambulando pelas paredes.

Em Cartum, ela também não conseguia, a seu próprio modo, entender o que ele estava dizendo. Todo aquele papo sobre o trabalho ser difícil era, obviamente, bobagem. Seu filho era brilhante. Seu filho sempre tirava as melhores notas da sala. Ela tinha uma fotografia de jornal que o mostrava aos dezesseis anos, quando atingira uma das notas mais altas no exame do ensino médio, apertando a mão do presidente, agora deposto. Para celebrar, o pai havia abatido um carneiro e distribuído a carne entre os pedintes que dormiam do lado de fora da mesquita vizinha. As irmãs haviam feito uma festa inebriante para ele, com cantos e danças. Ela, por sua vez, havia girado o turíbulo em círculos em torno da cabeça dele, e o feito pular para frente e para trás sobre o incenso, de modo a espantar a inveja e a maldade que 
certamente o rondavam. "99 no teste de matemática", ela havia repetido em êxtase para amigos e parentes. "99, e se você quer saber, eles tiraram aquele 1 ponto por pura mesquinharia, só pra não dar 100.”

"Tira essa ideia de desistir da cabeça”, disse-lhe na ligação de longa-distância.

"Você não entende que eu fui reprovado no exame de qualificação?" A palavra "reprovado" pendia pesada em sua língua. "O exame que eu preciso pra poder me inscrever no doutorado."

"Então faça de novo", ela insistiu. "Você vai passar, inshallah, e então vai vir passar o verão em casa. Eu mesma vou pagar a passagem. Não se preocupe.” Aquela mulher tinha seus próprios recursos, e quando desligou o telefone, um plano começou a se formar em sua mente. Demorou-se no caminho para casa, tramando e desejando. Algumas horas depois, revigorada pela siesta e pela xícara de chá com leite que sempre tomava ao pôr do sol, reuniu a família e lançou uma nova campanha: "Meu Pobre Filho Que Está Sozinho Em Londres Precisa De Uma Esposa." Foi assim que Majdy acabou se casando com Samra. Após ter batido a cabeça contra livros, ter se debruçado sobre as comprovações diversas vezes, ter copiado lambdas, gamas e sigmas curvilíneos do quadro negro e para o interior turbilhonado de seus sonhos, ele estava pronto para refazer o exame de qualificação. Em junho, voou para Cartum. Em julho, recebeu a boa notícia de que havia passado, e no final do verão estava voltando para Londres acompanhado da nova noiva.

Majdy conhecia Samra desde sempre, como a prima da melhor amiga de sua irmã, como a filha de fulano de tal. Entre eles, não chegou a haver um encontro repentino, nem um romance adolescente. Ele tinha memórias soltas dela: uma foto em preto-e-branco de uma criança apertando os olhos sob o sol; de pé com as irmãs dele e outras pessoas em frente à jaula das girafas no zoológico; uma adolescente de vestido azul e trança no cabelo segurando uma bandeja de garrafas de Pepsi na festa de noivado de um amigo. E a história horrenda que o havia fascinado na infância - Samra sendo mordida por um cachorro de rua e tendo que tomar trinta injeções antirrábicas na barriga.

Em 1985, ele a havia visto através de parreiras, de trás de uma garagem coberta sobre a qual as folhas subiam e teciam um labirinto entrelaçado. Ele estava apertando a campainha de uma casa próxima da universidade, em uma das menores vielas laterais onde moravam os funcionários da instituição. Na via principal, os estudantes se manifestavam contra a proposta de execução de um líder do partido de oposição. Enquanto eles marchavam por justiça, Majdy procurava o professor Singh, da cadeira de topologia, para implorar por uma carta de 
referência. Era para uma daquelas várias bolsas de pesquisa de pós-graduação que ele sempre buscava. De onde estava, conseguia ouvir os gritos, que lhe chegavam como ondas, subindo e descendo, ritmados e melodiosos, ainda que não fosse capaz de distinguir exatamente as palavras.

Eles nunca deixavam os estudantes chegarem muito longe; nunca os deixavam alcançar a praça do mercado, onde seus números engrossariam e causariam um tumulto, onde outras reivindicações e dores mais antigas se juntariam ao clamor contra a injustiça daquela uma morte. A privação poderia acabar espantando seu sono hipnótico e atacando no calor monótono do dia. Os estudantes desceriam University Road até a primeira rotatória e, então, o gás lacrimogênio os cegaria, os faria voltar correndo, tropeçando através da poeira e dos cartazes caídos no chão.

Ela e uma amiga vieram correndo e pararam sob a garagem coberta da casa ao lado à do professor; ela chorava. Chorava por causa do gás e dos risos. "Arrebentei minha sandália, tá destruída", ele a ouvir dizer. Ela a segurava na mão, as lágrimas correndo como parênteses em seu rosto coberto de poeira. Seu tobe havia caído, desabando em volta da cintura e joelhos, 326 e o cabelo havia escapado da trança que o amarrava e se espetava ao redor da cabeça em picos triangulares. Em sua nuca, pequenos cachinhos brilhavam de suor, escuros e lustrosos. Carregados de umidade, lá ficavam intactos e pareciam desligados de todo o resto, o gás lacrimogênio e a poeira, a sandália arrebentada, o tobe caído. Havia um zeer na frente da casa; ele a assistiu levantar a tampa de madeira, encher a caneca de lata com água e começar a lavar o rosto. Ela alisava o cabelo com água, procurando por grampos que então abria com os dentes e usava para prender os fios rebeldes.

E durante todo o tempo ela ria, chorava, fungava, e conversava com a amiga enquanto ambas puxavam as pontas de seus tobes sobre os ombros esquerdos, arrumando o tecido cuidadosamente no lugar e por cima dos cabelos.

“Essa sandália tá tão estragada que não dá pra usar nem de chinelo!”, disse a amiga.

Ele se sentia cínico ao observá-las, especialmente quando, agora que a manifestação havia debandado, outros estudantes começavam a passar por ali, xingando e cuspindo, com camisas rasgadas e os remanescentes patéticos de seus cartazes. Ele não tinha a raiva necessária para se juntar à manifestação, não tinha a habilidade necessária para saborear a adrenalina da rebelião. E no dia seguinte, como havia previsto, expôs-se a futilidade de toda a ação; Mahmoud Muhammad Taha foi enforcado em uma manhã de sexta-feira. 
Mais tarde, ou talvez no momento mesmo em que a observava através das parreiras, pensou, eu poderia ir falar com ela agora. Agora ela estaria acessível, sem formalidades, sem timidez. Agora, ela se entregaria a mim. E ao longo dos anos vamos falar sobre esse dia repetidamente e dizer que foi ali que tudo começou. Mas ele a deixou ir; apertou a campainha da casa do professor e logo ouviu os passos vindos do interior em sua direção.

É inútil resistir ao destino, impossível escapar de seus meandros, mas quem é capaz de distinguir seus padrões em meio a todo o ruído branco? Anos depois, quando a mãe levava sua campanha a cabo, o nome de Samra veio à tona. A irmã mais velha foi enviada para sondar o terreno. A recepção foi boa. Havia uma grande procura por noivos em potencial que vivessem no exterior (não importava aonde).

Brigaram assim que entraram no quarto dele em Londres, mas não pelo quarto ser pequeno e destinado a um estudante apenas. Ele já havia se inscrito para um alojamento de estudantes casados, mas a universidade ainda não lhes havia destinado um apartamento. A tensão começou assim que ela saiu do banheiro. Havia gotículas de água em seu cabelo e braços, as mangas da blusa arregaçadas.

“Cadê o seu tapete de orações?”, ela perguntou.

"Eu não tenho um", disse Majdy. Ele estava deitado na cama aproveitando a volta ao silêncio característico de Londres, o retalho de céu cinza que se movia e que ele podia ver pela janela, o deslizar de carros em ruas molhadas. Era como se Cartum o houvesse envolvido em um zunido triturante e eterno, e agora aquele roar estava agradavelmente ausente.

“Bom, o que você usa no lugar?” Ela já estava segurando uma toalha. "Qual é a qibla?"

Ele precisava descobrir a direção da $K a^{\prime} b a$. Da Grã-Bretanha, Meca estava a sudeste, é claro, pois a Arábia Saudita ficava a sudeste. Então neste quarto específico, para qual lado ela deveria se voltar? Onde exatamente estava o sudeste?

"Eu não posso acreditar", disse ela. "Você ficou aqui um ano inteiro sem rezar?"

Sim, ele tinha ficado.

"E as sextas? E quanto às rezas de sexta-feira?"

"Eu tenho aula nesses dias."

"Mate as aulas."

Ele se sentou. "Não seja burra, onde você pensa que você tá?" A expressão ferida que rapidamente apareceu no rosto dela fez com que ele se arrependesse de tê-la chamado de 
burra. Ele a abraçou e disse, "Eu não tô achando o curso tão fácil a ponto de poder fícar matando aula."

Ela sorriu e mostrou-se disposta a deixar a decepção de lado. Ele sugeriu que saíssem, então foram de ônibus até a Mesquita Central, onde ele comprou para ela um tapete de orações vermelho e uma bússola que apontava a direção de Meca. Ela também pegou um livrinho que listava os horários das rezas; cada página mostrava um mês, os dias dispostos em linhas e as diferentes rezas em colunas.

Sentada ao lado dele no ônibus, estudava o livreto. "Os horários mudam tanto ao longo do ano!"

“É por causa das estações”, ele explicou. "O dia é bem curto no inverno e bem longo no verão."

"Então no inverno eu vou ter que correr pra fazer uma oração atrás da outra, e no verão vão ter horas e horas entre a tarde e o pôr-do-sol." Ela havia dito "eu", não "nós”, o que a ele soou correto e respeitoso. Ela seguiria em frente sozinha, quer ele a acompanhasse, quer não. Ele estava aliviado por essa ida à mesquita tê-la satisfeito. Barato e sem aborrecimentos.

328 Com seu orçamento de estudante, ele dificilmente poderia arcar com restaurantes caros ou luxuosas idas às compras. Ainda bem que ela era uma garota simples de Cartum, nem exigente, nem materialista.

Ainda assim, ela queria que ele prometesse que mudaria e que faria de tudo para se comprometer com as rezas obrigatórias. Ela estava determinada a influenciá-lo, mas ele tinha vergonha da intimidade que as conversas sobre fé e prática religiosa evocavam. Afinal, eles não se conheciam tão bem assim e aqueles estavam sendo dias inebriantes de descoberta física; a pequenez do quarto fazendo-os esbarrar e esfregar-se um no outro. Ele era, naturalmente, o primeiro homem da vida dela, e ela oscilava entre o desconforto e o prazer, entre a falta de sono e a sensação de que toda sua juventude e beleza haviam-na trazido a este ponto: uma lua-de-mel em Londres, com as tatuagens de henna do casamento ainda nítidas em suas palmas e pés. Majdy tinha que admitir para si mesmo que estava cativado pelos confortos e delícias que ela oferecia, enfeitiçado por sua beleza e risada. Então ela estragava tudo ao falar de religião, ao relembrá-lo que sem aqueles cinco contatos diários a pessoa era capaz de ficar à deriva, sem proteção, ou graça, ou orientação. Ele não era um crente? Sim, com o coração dividido ele era, mas também era preguiçoso e desinteressado. Aqui em Londres, Majdy argumentava, rezar era uma alienação, uma interrupção e, acima de tudo, devido às mudanças de horário que seguiam o movimento do sol ao invés de os ponteiros do relógio, 
rezar era inconveniente. "Não me fale mais sobre isso", ele disse finalmente, puxando-a para perto. "Não enche."

Nos dias que viriam, quando ele voltou a ficar absorto no trabalho, sentia ela ao seu lado, solidária, ciente de seus humores, sensível a suas necessidades, gentil e generosa. Então ela se afastava para chapinhar no banheiro e voltava para rezar. Ela sustentava o dia com grampos. Cinco rezas, cinco grampos. O movimento do sol era marcado, o dia era mapeado, e Majdy sentia que sua vida se tornava mais estruturada; seu tempo, mais abençoado. No quarto abarrotado, o tapete de orações de Samra ocupava grande parte do chão; sobre ele ficava o velho tobe com o qual ela se cobria, jogado como uma pilha de pano enrolado. Às vezes ela o censurava com um olhar ou uma palavra, às vezes ela parecia triste e preocupada com ele, mas continuava a seguir seu próprio caminho, suas próprias obrigações, empenhada em preservar aquela prática mesmo longe de casa.

Ele queria que ela aproveitasse a viva e civilizada Londres. Queria que ela the fosse grata por tê-la resgatado do atraso de Cartum. Ele pensava que, como ele, ela acharia difícil no começo e em seguida se adaptaria, mas o que ocorreu foi o oposto. Durante os primeiros meses, ela até mostrou aprovação, como uma turista entusiasmada. Gostava de olhar as lojas, se empolgava ao ver quão fáceis eram os afazeres domésticos. Ela podia comprar carne já cortada, podia escolher dentre um monte de biscoitos e doces, que nem eram caros. Até as farmácias estavam tão repletas de remédios de tantas cores e sabores diferentes que ela quase desejava ficar doente. Cada objeto que ela tocava era perfeito; a qualidade irradiava de cada coisinha. A cor dos grampos de cabelo não descascava sob suas unhas como sempre acontecera; o chiclete não era o graveto quebradiço que em geral se dissolvia em sua boca na primeira mordida. Potes de geleia vazios eram objetos de beleza; ela os lavava, secava, e não era capaz de jogá-los fora. As latas de biscoito, ela queria colecionar e levar para casa, onde sua mãe as usaria para guardar farinha ou açúcar, ou colocaria nelas seus próprios bolos e orgulhosamente mandaria uma lata para a vizinha, e dias depois a vizinha devolveria a lata contendo outro presente.

Ela engordou. Escreveu cartas felizes para a família. Majdy mostrou-lhe a biblioteca da universidade - eram tantos andares que havia elevadores e até mesmo banheiros dentro! Passearam pelas reluzentes salas de computadores e ela as achou impressionantes. Ela fazia com que ele se achasse brilhante, e no fundo ele sabia que era mesmo. Então os dias ficaram mais curtos, tornaram-se monótonos. Ela estava como o turista de fim-de-semana que começa a se cansar de seus arredores exóticos. Tudo ao seu redor passou a parecer transitório, 
desconectado da vida normal. Isso passou a acontecer quando Majdy começou a falar de conseguir um visto de trabalho após o visto de estudante expirar, de não voltar para o Sudão quando terminasse o doutorado.

O que ela achava mais estranho era a continuidade. Chovia e as pessoas abriam os guarda-chuvas e seguiam seu caminho; as prateleiras do supermercado ficavam vazias e enchiam-se novamente. O carteiro entregava a correspondência todos os dias.

“As suas aulas nunca são canceladas? Os seus professores não ficam doentes? As esposas deles não têm filhos? Quando a rainha morrer, vão dar folga pra todo mundo?"

"Ela vai morrer num domingo", dizia ele, rindo de suas perguntas. "Isso que é civilização, é a segurança de construir a vida, e de fazer algo com ela. Não ficar o tempo todo travado por golpes de estado e leis novas, ou ficar o dia inteiro esperando numa fila pra conseguir combustível, ou não conseguir levar o filho doente no médico porque os médicos estão em greve."

Ela ouvia tudo o que ele dizia atentamente; concordava com a cabeça, mas seus olhos continuavam desconfiados. No entanto, quando ela falava sobre o futuro, imaginava que eles voltariam para casa, como se as esperanças dele de ficar em Londres fossem apenas sonhos, ou como se as esperanças dele fossem algo inevitável que ela desejava negar. "Eu imagino você chegando em casa mais cedo", dizia ela. "Não teria esse dia de trabalho infinito que tem aqui.

“A gente dormiria de tarde embaixo do ventilador, as pás um borrão cinza; o sol tão forte e brilhante que bateria na gente mesmo com as persianas fechadas. Eu iria te provocar com perguntas sobre os seus alunos - as meninas são bonitas? Elas vão no seu gabinete depois das aulas e dizem de um jeito doce, 'Ustaz, eu não consegui entender isso, não consegui entender aquilo'? 'Ustaz, não seja tão duro com a gente durante as provas.' E você iria rir de mim e balançaria a cabeça, diria que eu tava falando bobagem, mas eu saberia pelo seu olhar que você gostava quando eu era possessiva. A gente acordaria com as crianças brincando no telhado, o baque dos passos delas mais alto que o trauteio do ventilador. Elas não podem subir lá. Não é seguro por conta dos pedaços pontudos de vidro verde que servem pra espantar ladrões. E você tá furioso; você vai lá fora e joga o chinelo no seu filho enquanto ele desce da árvore apoiando um pé no parapeito da janela. Esse é o mais velho, o que sempre começa tudo. Mas ele é malandro e se abaixa; você erra e tem que gritar, 'Traz o chinelo de volta!' De dentro da casa eu ouço a risada dele como uma cascata de água fresca. Uma vez você chegou a comprar um chicote por conta desse menino. Você comprou num bazar em 
Umdurman, onde vendem bons chicotes, e ficou bem satisfeito com você mesmo naquele dia. Você chicoteou o ar pra assustar as crianças com seu poder serpentino. Mas você nem teve a chance de usar porque o moleque pegou o chicote e jogou em cima do telhado do vizinho e lá ele ficou entre as bolas de pó, lâminas de barbear e outras coisas que o vento carregava praquele telhado.

"Eu faria chá com menta. Mas agora o sol já teria quase se posto. Seria a parte mais quente do dia, sem brisa, sem movimento, como se o mundo inteiro estivesse segurando a respiração pra partida do sol. Nosso vizinho vem na nossa casa e vocês bebem o chá juntos. Ele traz com ele as últimas fofocas, outro fiasco político, e você se diverte. Seu bom humor retorna. Seu filho se comporta bem na frente das visitas; ele para de brincar, vem e aperta a mão do homem. O som de luto corta a imobilidade da noite, como uma revoada de pássaros gritando, circulando e grasnando com suas gargantas. Imaginamos que deva ser o vizinho ancião do outro lado da praça; fazia um tempo que ele vinha entrando e saindo do hospital. Eu pego meu tobe e corro, corro com meus chinelos pra lamentar com eles."

“Mulher, você tá alucinando." Foi a resposta de Majdy. Ele podia provar. "Primeiro de tudo, eu nunca, com o salário que a universidade paga aos professores, poderia comprar uma casa ou apartamento pra gente. A não ser que eu roubasse ou aceitasse propina, e não tem muita oportunidade pra fazer nenhuma das duas coisas no tipo de trabalho que eu faço. A gente provavelmente iria morar com os meus pais; minha mãe iria acabar te irritando mais cedo ou mais tarde. Você vai reclamar dela dia e noite, e vai ficar brava comigo porque você espera que eu fique do seu lado e eu não fico. Em segundo lugar, como eu poderia ir até o bazar de Umdurman sem combustível? E dificilmente haveria energia elétrica pro seu ventilador. E por último, por que você parte do princípio que nada me agrada mais do que tomar chá e fofocar com o vizinho? Esse é exatamente o tipo de perda de tempo do qual eu quero me livrar. Toda aquela atmosfera em que supostos intelectuais passam o tempo discutindo política. Cada professor sendo definido por suas convicções políticas, cada promoção dependendo da inclinação política do sujeito e não da quantidade de pesquisa que ele fez ou dos artigos que publicou. Meus colegas imaginariam que é responsabilidade deles conduzir o país. Debatendo cada coisinha a partir de cada ângulo abstrato. Os ingleses desistiram, arrumaram as coisas e foram embora sem lutar, e de alguma forma os sudaneses carregam esse ar de orgulho, de crença que esse país maluco e vasto deles um dia vai se erguer graciosamente de seu atraso e entregar algo de bom!" 
Às vezes ela contra argumentava quando ele falava daquele jeito, acusava-o de deslealdade, de falta de compaixão. Às vezes ela ficava em silêncio por dias, se controlava e não mencionada nem o futuro nem o passado. Então, como alguém quebrando um jejum, ela falava, oferecendo a ele memórias e estórias, e esperava que ele as absorvesse. Esperava com a mesma paciência, a mesma insistência serena com a qual as garotinhas do Correio Central haviam oferecido grampos e chicletes para a mãe dele.

"Eu não tô inventando", disse ela uma noite enquanto eles andavam por um caminho lateral, lustroso pela chuva e a luz amarela dos postes. "Isso realmente aconteceu. Depois que a sua mãe te telefonou do Correio Central ela ficou uma hora esperando um ônibus ou táxi. Nenhum dos dois veio; o transporte tava complicado naquele dia por conta da falta de combustível. O sol queimava a cabeça dela e ela ficou exausta de ficar em pé. Então ela andou até a estrada, ficou bem no meio da estrada e levantou a mão, mostrando a palma. Parou o primeiro carro, abriu a porta da frente e entrou. 'Meu filho', disse pro motorista, 'eu tô de saco cheio de esperar o transporte público e eu não consigo dar mais um passo. Pelo amor de Alá, me leve pra casa. Vou te mostrar o caminho.' E ele de fato levou ela pra casa, mesmo não sendo caminho pra ele. E enquanto eles conversavam, ele chamava ela de "tia'."

E em julho uma chuva que formava poças prateadas. O sol desaparecendo por um dia, o novo cheiro de terra. E não houve trabalho naquele dia, nem escola. Os carros eram ilhas perdidas nas ruas inundadas.

"Porque não têm esgotos decentes", ele dizia a ela. "Não tem sistema de drenagem e ainda todos aqueles buracos nas ruas. Lembre do fedor da água parada uns dias depois. Lembre dos mosquitos que apareciam, espalhando doenças."

"Poças prateadas", ela dizia, "sob um céu estranho de nuvens azuis."

Outra lembrança. Ela a ofereceu como uma flor espremida para dentro das mãos dele. Na semana anterior ao casamento, eles haviam ido visitar o tio dele. A luz acabou e o roar do ar-condicionado tornou-se um ronronado, suas pás batendo, e então todo o som cessou. A escuridão repentina, o silêncio repentino. Sentados, eles ouviram o delicado plim, plom da água caindo do caninho fresco do ar condicionado; então abriram as janelas para deixar entrar o tênue ar da noite e os perfumes dos arbustos de jasmim. A luz da lua preencheu a sala com sombras cinza-azuladas. Silhuetas subiam dos doces coloridos em cima da mesa, o gelo derretendo nos copos de limonada. Enquanto seus anfitriões tropeçavam em busca de velas e lanternas, Majdy havia se curvado e a beijado pela primeira vez. 
"Mas, Samra, você quer uma falta de energia em Londres? Pense nisso - elevadores, sinaleiros, os trens. Caos e medo. Eles escreveriam sobre isso nos jornais, falariam disso na TV. E em Cartum é um evento de todo dia, mais um inconveniente, parte da miséria da vida. Geladeiras descongeladas viram armários com a comida toda empapada e apodrecida dentro."

Às vezes ele olhava para ela e sentia compaixão. Sentia que, sim, ela não pertencia a este lugar. Olhava para os cachinhos na nuca dela, agora secos e leves, não úmidos de suor, e pensava que ela era feita para pores do sol brilhantes e vestidos leves de algodão. Seus pequenos dentes eram feitos para arrancar a casca dura da cana-de-açúcar; suas covinhas nas bochechas, para amigos e vizinhos. Ele podia vê-la conversando folgadamente, tricotando fofocas com uma amiga. Passando o tempo à sombra de palmeiras e buganvilas, em um lugar onde as horas demoravam a passar.

Contudo, a maior parte das vezes ele não conseguia entender como ela não estava empolgada com as oportunidades contidas na nova vida deles, como ela podia não admirar a maneira civilizada como as pessoas faziam as coisas aqui, a eficiência e decência delas, ambulâncias e carros de bombeiro que nunca deixavam ninguém na mão. A forma como um cartão de débito podia deslizar por uma fenda na parede e fazer emergir dinheiro fresco. Essas coisas a impressionaram, mas não por muito tempo. Ela exclamava sobre como pombos e patos eram deixados em paz nos parques. Ninguém os capturava para comer. Mas ao invés de aproveitar sua beleza, ela ruminava sobre quão pobre seu próprio povo era.

Ele começou a ver a saudade que ela tinha de casa como uma coisa perversa. A relutância incondicional em abraçar a nova vida deles, uma intransigência. Ele começou a se entediar com a nostalgia dela, a inabilidade em mudar ou iniciar uma vida nova para si mesma. A saudade de casa estava bloqueando o progresso dela, cegando-a a todos os benefícios que poderia ter. Havia tantas escolhas, tantas portas novas, e ainda assim ela estava presa ao passado, adorando o Sudão e deixando o momento presente passar. Ele havia, no tempo que passara em Londres, conhecido mulheres sudanesas que desabrochavam em seu novo ambiente. Ela as havia visto com calças justas que não ousariam usar em casa, brincando com cigarros acesos nas mãos. E ainda que ele não esperasse ou mesmo não quisesse que ela fizesse exatamente aquelas coisas, estava decepcionado por ela não ter capturado aquele mesmo espírito e, ao contrário, parecia mais tímida, mais reservada do que jamais fora em Cartum. Ela queria usar o tobe, cobrir o cabelo, e ele dizia, "Não, não, aqui não. Eu não quero que nos associem com fanáticos e com atraso." 
É assustador chegar em casa no fim do dia e encontrar sua esposa sentada, apenas sentada, de camisola e com o cabelo despenteado exatamente como você a deixara de manhã. Ela que confere o reflexo em todos os espelhos, que por você perfuma os cabelos com sândalo, que mergulha aço em tinta preta para delinear os olhos. Você a encontra sentada e o lugar inteiro está intocado - sem cheiros de cozinha, a cama desfeita, canecas manchadas de chá, os poucos flocos de cereais restantes inchados no pote. Ela está em silêncio, olha para você como se você não existisse, não cede ou se suaviza sob seu toque. Afague o cabelo dela e esfregue suas mãos e procure as palavras corretas, as que ela quer ouvir. Fale de jardins com perfume de jasmim, de uma dança de festa de casamento, do alto Nilo quebrando nas margens. Até que ela consiga chorar.

Pelos dias que se seguiram, enquanto Majdy colocava a chave na fechadura, enquanto a girava, se preparava para aquela mesma cena, temendo uma recorrência. Ele estava feliz naquele dia. Enquanto ela ficava sentada em casa com o coração congelado, ele havia vislumbrado um módico sucesso, um ligeiro avanço no trabalho. Um artigo que ele vinha procurando, um artigo escrito cinco anos antes na mesma área de pesquisa dele, encontrava-se em outra biblioteca. E ele havia ido lá, àquela faculdade no outro lado de Londres; isso em si um grande evento, já que ele sempre estava na biblioteca ou usando os computadores centrais. Ele havia encontrado o artigo, tirado xerox, se entusiasmado com sua notação familiar e voltado, em plena apreciação por aquele meticuloso corpo documental, pela tecnologia que possibilitava as pessoas localizarem materiais escritos. "A gente tá séculos atrasados", ele diria a ela mais tarde, "em coisas assim, a gente tá tão pra trás que não tem nem como alcançar mais." E enquanto ela havia ficado sentada de camisola, imóvel, ignorando a fome e a sede, ele havia entrado na mente daquele outro matemático, seguido sua lógica e, ao encontrar um erro (o expoente de lambda deveria ser "t-1", e não " $t$ "), um erro de digitação ou um deslize mais sério do autor, ele havia sido tomado por um sentimento de prazer. Tanto que mesmo quando ele se ajoelhou perto dela e perguntou, “Tá tudo bem? O que aconteceu?", a fórmula com seus phis e gamas e lambdas ainda saltitava por seu cérebro e lhe ocorreu a ideia de que o nome dela, se ele ignorasse o significado real em árabe, soava exatamente como aquelas letras gregas, aquelas variáveis enigmáticas com suas formas suaves e curvas delicadas. Alfa, lambda, sigma, beta, samra.

Ele propôs uma solução prática para o problema dela. Ela deveria fazer algo consigo mesma; estava muito ociosa, e como não podia trabalhar sem visto, então deveria estudar. Seu inglês já era bom, então o ideal seria processamento de textos; ela poderia digitar a tese para 
ele. Estava empolgado com a ideia; um curso de processamento de textos por algumas semanas, e talvez ali ela acabasse conhecendo outros como ela, vindos de várias partes do mundo, fazendo amigos e se mantendo ocupada. Então ela, que um dia enfrentara gás lacrimogêneo, o som de pés correndo, agora encarava uma professora de meia idade, uma mulher alegre que havia recentemente viajado de férias para a Tunísia e voltado revestida de cafetãs e xales. A professora despejou sobre Samra, "Você deve estar tão aliviada de estar aqui, com toda aquela guerra e fome no seu país. Você deve estar aliviada de não estar lá agora." Frente a tal mulher, Samra se recolheu e, como uma criança mimada e teimosa, recusou-se a continuar o curso.

Por desespero, Majdy sugeriu que ela voltasse para casa por alguns meses. Estremeceu ao vê-la tentar esconder o entusiasmo na voz ao dizer, "Sim, seria legal." E as perguntas educadas: a passagem não era muito cara? Ele iria ficar bem sozinho? Então ela se foi, facilmente, tão facilmente, como se nunca tivesse realmente chegado, nunca tivesse estabelecido raízes que precisassem ser arrancadas.

Sem ela, a sensação de repente passou a ser aquela do ano que ele havia passado sozinho em Londres antes de eles se casarem. Os dias se aglutinavam, nenhuma razão para ir para casa à noite, uma quietude excessiva à sua volta. Sem ela, ele não sabia direito como organizar o dia, se trabalhava em casa ou na biblioteca, se trabalhava até tarde da noite ou se acordava cedo de manhã. Ele sabia que tanto fazia, mas aquela primeira centelha de liberdade que havia caracterizado os primeiros dias de ausência dela, aquela sensação de alívio, de soltar o peso de uma responsabilidade, logo se dissiparam e a liberdade passou a rodeá-lo, rançosa e pesada.

Enquanto Samra estava longe, Londres tornou-se mais familiar para ele. Pensava na cidade como sua nova casa e era como se ela respondesse. Podia senti-la se suavizando em torno dele, tornando-se cordial pela velhice, os verões ficando cada vez mais quentes. Um novo calor úmido, grudento, diferente da queimação seca do deserto no Sudão. As pessoas enchiam as ruas, os parques, a explosão populacional, ou como se um período de encarceramento houvesse terminado e agora elas estavam soltas. Eles ficavam deitados imóveis sobre toalhas estendidas na grama, dirigiam carros conversíveis, derramavam-se de cafés por sobre as calçadas.

Pedintes se acocoravam ao redor das estações de metrô, ao estilo do Terceiro Mundo. A visão dos pedintes o perturbava; ele não conseguia encará-los, não conseguia dar dinheiro. Não parecia certo, dava uma sensação estranha que pessoas brancas fossem pobres. Era 
vergonhoso que eles fossem sem-teto e estivessem esmolando. Não era natural que ele estivesse melhor que aquelas pessoas. Ele tinha uma leve lembrança de ter descoberto que pedir esmolas era ilegal na Europa. A informação, incrível e surpreendente, compunha, na cabeça dele, parte da magia do mundo ocidental, um lugar onde o sustento de cada um estava tão garantido que mendigar pudesse ser considerado um crime.

Uma vez ele dissera a Samra que este país dilapidava a fé das pessoas, mas começou a ver que ele dilapidava qualquer fé, indiscriminadamente, incluindo até a fé que as pessoas colocavam no país. E enquanto o país o aceitava, enquanto sua admiração por aquela terra ficava mais firme, sua fé no lugar fraquejava. Não era mais o suficiente, como fora uma vez, que ele estivesse aqui, que ele tivesse o privilégio de andar pelas ruas de Londres, de sentir o cheiro dos livros de suas bibliotecas, de banquetear seus olhos com os carros novos e brilhantes. Ele andava em ruas molhadas que nunca sofriam enchente e percebia que ele jamais saberia como seria dizer, "Meus ancestrais construíram isso", ou, "Meu avô pegou um livro emprestado nessa biblioteca." Londres tinha algo que nunca seria dele, que era impossível para ele aspirar.

336 A mãe telefonou, falando mais alto que os sons alvoroçados do Correio Central. "Por que você mandou a Samra de férias pra cá tão cedo? Tem alguma coisa errada entre vocês?"

Ele foi pego de surpresa. "Não, claro que não." Casar-se com Samra o havia ajudado a sentir-se instalado e confortável, bem alimentado e cuidado. Ele gostava de trabalhar até tarde da noite, tinha a companhia dela, o som da colher enquanto ela mexia o açúcar no chá, o repique das pulseiras, seus movimentos quando ela se levantava para rezar naquele amanhecer precoce de verão. "Ela reclamou de alguma coisa?"

"Não.” A voz da mãe era descontraída. "Ela só comentou que você não reza."

“Ah.” Ele não conseguia pensar em uma resposta. O corredor do alojamento estava vazio. Ele olhava para a máquina de venda automática, com chocolates e bebidas. Samra tinha ficado fascinada com essa máquina. Tinha tentado fazê-la funcionar com moedas sudanesas. Ele tinha saudades dela.

"É verdade que você quer continuar em Londres depois que conseguir o título?" Era por isso que ela tinha telefonado. A pontada de ansiedade.

“Sim, pra mim seria melhor." Seu doutorado agora estava ao alcance das mãos. Fora convidado para um congresso em Bath. Estava conseguindo se inserir, e depois de todo esse trabalho, tinha a intenção de ficar e colher o que havia plantado. 
Do outro lado da linha, a mãe arfou, "Como você pode me deixar sozinha na minha idade?"

Ele sorriu, pois tinha irmãos e irmãs morando em Cartum. Não havia necessidade para aquela resposta melodramática. "Você não quer o melhor pra mim? Você é a que tá sempre reclamando que o Sudão vai de mal a pior."

A mãe suspirou. Primeiro ele tinha ameaçado abandonar os estudos e voltar para casa sem o título; agora ele estava ameaçando o contrário! Ela tinha feito ele se casar para que não se afastasse, para que ficasse por perto. "Mas e se as coisas melhorarem aqui, filho? Se eles encontrarem petróleo ou estabelecerem a paz, você não estaria deixando tudo isso passar?"

"Eu não posso decidir o meu futuro com base em especulações.” Simular um sistema ao longo do tempo, construir um modelo, brincar com um conjunto de variáveis, observar o que acontece quando você introduz um choque - este era seu trabalho.

De volta ao quarto, Majdy reparou no silêncio. O chão parecia estranhamente maior. Samra havia dobrado o tapete de orações e guardado no lado dela do armário. Não precisava levá-lo consigo. Em Cartum havia muitos outros tapetes, tapetes com remendos apagados e gastos nos lugares onde as pessoas pressionavam suas testas e ficavam de pé com os pés molhados. Majdy abriu o armário e tocou o material aveludado e macio. Este agitou nele uma sensação infantil de exclusão, de ser deixado de fora, como um prazer que ele houvesse negado a si mesmo e agora tinha esquecido o porquê. Ela havia sustentado o dia com grampos - não apenas os dias dela, mas os dele também. Cinco grampos. E agora a manhã esvoaçava em tarde, em noite, sem marcas.

\section{REFERÊNCIAS}

ABOULELA, Leila. Missing out. [2010] In: HABILA, Helon (Ed.). The Granta Book of the African Short Story. London : Granta Books, 2011.

AKBAR, Arifa. Elsewhere, Home by Leila Aboulela - review. In: The Guardian, 09/07/2018. Disponível em: https://www.theguardian.com/books/2018/jul/09/elsewhere-home-leilaaboulela-review Acesso em 05/04/2019

BRITTO, Paulo Henriques. A tradução literária. Rio de Janeiro : Civilização Brasileira, 2016.

HABILA, Helon. Introduction. In: HABILA, Helon. (Ed.) The Granta Book of the African Short Story. London : Granta Books, 2011.

MESCHONNIC, Henri. Pour la poétique II: épistémologie de l'écriture : poétique de la traduction. Paris : Gallimard, 1973. 
* Ana Luiza de OLIVEIRA E SILVA - Graduada em História (2005) pela Universidade Federal do Paraná. Especialista em Ensino de Línguas Estrangeiras Modernas (2011) pela Universidade Tecnológica Federal do Paraná. Mestre (2009) e Doutora (2016) em História Social pela Universidade de São Paulo. Pesquisadora do Canadian Council for International Cooperation (CCIC-CCCI). Ottawa, Ontario, Canadá.

Currículo acadêmico: http://lattes.cnpq.br/2796838146812379

ORCID: https://orcid.org/0000-0002-3998-8437

E-mail: analuiza.oliveiras@gmail.com

1 A publicação desta tradução de "Missing Out" para a língua portuguesa foi autorizada por The Gernert Company, responsável por agenciar a autora Leila Aboulela. A autorização foi feita por e-mail no dia 27 de agosto de 2019 e pode ser solicitada à tradutora.

2 De acordo com uma postagem no Facebook da autora, datada de 3 de dezembro de 2013, seu conto foi traduzido por Adil Babiker e publicado na Aldoha Magazine. Contudo, esta versão parece indisponível na internet, e o próprio site da revista parece não existir mais.

${ }^{3}$ Aboulela (2011, p. 215, 231)

4 “[...] I would ask myself a simple question: ten years from now, would this story illuminate the preoccupations and concerns, literary and social, of the times in which it was written?" (HABILA, 2011, p. xiv)

${ }^{5}$ Britto (2016, p. 80-81)

${ }^{6}$ Britto (2016, p. 86-87)

${ }^{7}$ Britto (2016, p. 92-106) 